Int. J. Electrochem. Sci., 15 (2020) $12578-12586$

International Journal of

ELECTROCHEMICAL

SCIENCE

$\underline{\text { WWW.electrochemsci.org }}$

Short Communication

\title{
Phytic Acid Assisted Formation of Phosphorus-Doped Graphene Aerogel as Electrode Material for High-Performance Supercapacitor
}

\author{
Gaosheng Nie ${ }^{1, *}$,Hangchun Deng ${ }^{2}$, Jie Huang ${ }^{2}$, Chunyan Wang $^{2}$ \\ ${ }^{1}$ School of Internet of Things, Jiangxi Teachers College, YingTan, Jiangxi, 335000, China \\ ${ }^{2}$ East China University of Technology, Nanchang, Jiangxi, 330013, China \\ *E-mail: $\underline{\text { 18970187308@163.com }}$
}

doi: $10.20964 / 2020.12 .32$

Received: 1 August 2020 / Accepted: 30 September 2020 / Published: 31 October 2020

In this study, a simple solvothermal method was used to prepare a highly porous phosphorus-doped graphene aerogel (PGA), using graphene oxide (GO) as the precursor and phytic acid as the dopant. The morphostructural characterization of PGA was conducted by scanning electron microscopy (SEM) and X-ray photoelectron spectroscopy (XPS). For supercapacitor applications, PGA materials showed superior capacitance performance $\left(225.3 \mathrm{~F} \mathrm{~g}^{-1}\right.$ at $\left.1 \mathrm{~A} / \mathrm{g}\right)$ and long-term cycle stability. The specific capacitance retention rate reached $95 \%$ after 10,000 charge and discharge cycles. Even if the current density was doubled after 10 times, it can reach $196.8 \mathrm{~F} \mathrm{~g}^{-1}(10 \mathrm{~A} / \mathrm{g})$. The as-prepared PGA in this study has the advantages of low cost, safety, reliability, and excellent electrochemical performance, and thus has superior application potential.

Keywords: phosphorus-doped graphene aerogel, electrode material, supercapacitors

\section{$\underline{\text { FULL TEXT }}$}

(C) 2020 The Authors. Published by ESG (www.electrochemsci.org). This article is an open access article distributed under the terms and conditions of the Creative Commons Attribution license (http://creativecommons.org/licenses/by/4.0/). 